\title{
Ethnic Categorization \& Organizational Crisis Management in Multi-Ethnic Societies
}

\author{
Meksley Nwagboh \\ Pan Atlantic University
}

Increasing business interests in multi-ethnic emerging economies as a result of the opportunities they offer for trade and investments, expose organizations operating there to ethnic group rivalries and conflicts. Despite this growing threat, little has been documented on the role of ethnicity in shaping perceptions of corporations and organizational crises. This study proposed an ethnic attribution framework for understanding organizational crises in multi-ethnic settings, laying as its foundation the assumption that stakeholders in multi-ethnic societies perceive organizations along ethnic lines. The study identifies some of the factors responsible for ethnic categorization and suggests the ethnic inclination of stakeholders would be positively related to the ethnic categorization of organizations. Drawing from a sample of 158 stakeholders, this study found reports of ethnic categorization of organizations driven primarily by the lack of diversity amongst staff. The findings assert that in multi-ethnic societies, the application of an ethnic frame to an inter-organizational crisis is a function of the attribution of ethnicity to the corporate organizations involved in the crisis.

Keywords: ethnic categorization, organizational crisis, ethnic attribution crisis, organizational crisis, ethnicity groups

\section{INTRODUCTION}

Corporate organizations in twenty-first-century business environments are continually threatened by the possibility of experiencing a crisis and the daunting task of managing it. The last three decades have witnessed a surge in crisis management studies, with considerable attention devoted to unearthing the triggers (Coombs \& Holladay, 2002; Perrow, 1984; Taylor, Coombs, \& Holladay, 1995), and the ways through which it can be effectively managed (Barton, 2001; Civelek, Cemberci, \& Eralp, 2016; W. Liu, Lai, \& Xu, 2018)

Despite incessant interests in the field, calls have been made for further reconsideration of the theoretical underpinnings and mechanisms of organizational crisis in multi-ethnic environments (Pearson, Roux-Dufort, \& Clair, 2007). Despite the different theoretical perspectives utilized in organizational crisisrelated studies, literature on multi-cultural approaches remain few and underdeveloped, despite society becoming more ethnically diverse (Falkheimer \& Heide, 2006). Though there appear to be growing interests in cultural and racial crisis studies (Baker, 2001; Brinson \& Benoit, 1999; Coombs \& Schmidt, 2000; B. F. Liu \& Pompper, 2012; W. G. Peacock \& Ragsdale, 1998; Waymer \& Heath, 2007; Williams \& Olaniran, 2002) and examinations of prejudices against racial minority groups (Adamson, McNatt, \& Bray McNatt, 
2000; Barton, 1993; Chin, Naidu, Ringel, \& Snipes, 1998), a review of the available literature reveals an absence of theoretical or empirical documentation on ethnic categorization of corporate organizations.

In a bid to fill this void, this study presents a multi-cultural perspective to stakeholders' perception of organizational crises. It builds an ethnic attribution framework for understanding organizational crises in a multi-ethnic environment like Nigeria. It further investigates the extent to which stakeholders ethnically categorize corporations and how such categorizations influence their attributions of blame during a crisis.

\section{CONCEPTUAL CLARIFICATION}

\section{Organizational Crisis}

Coombs (2007) conceptualized crisis as a situation that threatens the legitimacy of an organization and a breach of stakeholders' normative expectations from an organization. Bundy et al., (2017), drawing from a convergence of definitions from studies between 1998 and 2015, defined organizational crisis to be an event commonly understood by managers and stakeholders alike, to be salient, unexpected, potentially disruptive, and distinguished by four features: (1) source of uncertainty, disruption and change (2) potentially dangerous, harmful or threatening (3) behavioural phenomenon and (4) part of larger processes (Bundy \& Pfarrer, 2015; Bundy, Pfarrer, Short, \& Coombs, 2017; Gephart, 2007; Jacques, 2009; James \& Wooten, 2011; Kahn, Barton, \& Fellows, 2013; Lampel, Shamsie, \& Shapira, 2009; Pearson \& Clair, 1998; Roux-Dufort, 2007). Ulmer et al (2015) simplified these characteristics to include the element of surprise, threat and short response time, while Falkheimer \& Heide (2006) similarly defined organizational crisis along the characteristics of significant threat, unpredictability and urgency (Falkheimer \& Heide, 2006; Ulmer, Sellnow, \& Seeger, 2015). Regardless of the definition used, the underlying feature of organizational crisis remains the significant threat it poses to disrupting the operations of organizations (B. K. Lee, 2005)

Instrumental to the crisis management process is an understanding of the interpretation stakeholders allot a crisis and the factors that influence the attributions of blame by stakeholders (Laufer \& Coombs, 2006). Weiner's (1986) Attribution theory and Coombs's (1995) Situational Crisis Communications theory stipulate the factors of stability, locus of causality, controllability, prior history, organizational reputation and severity of damage as contributing factors for the attributions of blame (Coombs, 1995; Weiner, 1986). However, it would appear that in plural societies, these factors do not account for perceptions of crisis occuring as a result of ethnic sentiments (Falkheimer \& Heide, 2006). In today's ethnically diverse environment, the socio-cultural context of crisis is becoming increasingly important.

\section{Ethnic Groups}

Ethnic groups comprise individuals bonded by a common culture and a shared distinctiveness in ancestry, language, myths, religion, food and dressing (Okolie, 2003). This sense of commonality remains a recurring feature in most ethnic group descriptions, albeit to varying degrees. Even though the common characteristics of culture, ancestry, language, religion and territory exist among ethnic groups, it is really the sense of a shared identity among members (in-group) that distinguish them from other ethnic groups (out-groups). Without this sense of shared identity, the concept of ethnicity remains weak until it is objectified through self-identification with an ethnic group, recognition by others within the ethnic group, and differentiation from other ethnic groups (Angerbrandt, 2015; Hussain \& Bagguley, 2015; Kim, 2004; Osaghae, 1995; Ukiwo, 2005).

\section{Nigeria's Multi-Ethnic Environment}

Ever since the amalgamation of the northern and southern protectorates in 1914, Nigeria has been described as a plural society with several ethnic groups co-existing within a geographical boundary despite their cultural differences (Oguntola-Laguda, 2008). Presently, Nigeria has three major ethnic groups (i.e. Hausa, Yoruba and Igbo) and over 364 minority ethnic groups (Nnoli, 2008). With the limited resources available, different ethnic groups lay claims of superiority over others in the struggle for economic resources, regional wealth and political appointments (Trager, 2001).Thus, ethnicity is increasingly 
becoming the currency for navigating through society. The growing level of ethnic polarization engulfing the country and the extent to which the widespread propagation of 'us versus them' mentality has triggered all manner of ethnic divisions and impeded the quest for national unity (Nwaoga, Nche, \& Olihe, 2014; Osaghae, 1995; Owede, Rasheed, \& Arunah, 2016).

\section{Ethnic Perceptions \& Corporate Organizations}

Ethnic plurality in any society inescapably births a multi-ethnic workforce within organizations and if mismanaged, can affect inter-group relations and create ethnic perceptions about corporate organizations (Johns, 2006; Pugh, Dietz, Brief, \& Wiley, 2008). Several scholars have argued that the environment in which organizations operate, significantly impact organizational behavior, inter-group relations at work, and stakeholder perceptions about the organization (Brief, Butz, \& Deitch, 2005; McKay et al., 2007). While perceptions of ethnic groups are formed outside the work environment, they are carried into the workplace by members of society. This, in turn, may have severe implications for inter-group relationships within the office and in the long-term, perceptions of stakeholders regarding the organization (H.-J. Lee, 2016).

External factors such as religion, politics, and ethnic factors shape the mindset of employees so much so that in the event society experiences political, religious, or inter-ethnic conflicts, such rivalries transcend into the workplace (Lee \& Reade, 2015) This implies that individuals with strong ethnic membership ties are more likely to interpret and classify the world around them through an ethnic frame and, in the process, become more aware of their ethnic similarities with other individuals within the work environment. A preponderance of an ethnic group within an organisation's workforce may create perceptions of ethnic bias for that organization.

More importantly, corporate organizations in failing to diversify their workforce, run the risk of being ethnically categorized in line with the dominant ethnicity of its board, management and staff (Tajfel \& Turner, 1979). Parallel to the social categorization process used in categorizing individuals into groups (Turner, Hogg, Oakes, Reicher, \& Wetherell, 1987), organizations can be categorized by stakeholders as belonging to an ethnic group based on perceptions of the lack of ethnic heterogeneity amidst their workforce (Abrams \& Hogg, 1990; Lee \& Reade, 2015). Thus, references such as 'South African company', 'Lebanese restaurant', 'Yoruba bank', 'Igbo trader', 'Chinese company, 'Hausa Firm', 'White school', 'Black coffee shop' are used casually in describing certain corporate organizations, indicating stakeholders' categorization of organizations.

\section{Ethnic Attribution Crisis}

The categorization of corporations along ethnic lines has far-reaching consequences especially during crisis. Often times, ethnically categorized organizations get entangled with crisis they are oblivious to. A striking example points to the 2019 xenophobic attacks on black foreign nationals in South Africa which triggered retaliatory attacks on MTN, a telecommunications giant in Nigeria perceived to be of South African origin (Kabir, 2019). In this case, MTN experienced crisis due to the ethnic label (i.e., South African Company) ascribed to it by stakeholders in Nigeria. Another example is the boycott of Danish products in the Middle East as a result of the 'unsavory' depictions of the Prophet Mohammed in a Danish newspaper (Frandsen \& Johansen, 2005). Muslims in Saudi Arabia and the rest of the Middle East expressed their anger towards Arla foods, a Danish company operating in the Middle East even though it had no direct involvement with the newspaper publication. Furthermore, the French department store chain, Carrefour,experienced boycott by the Chinese in 2008. The Olympic torch had been extinguished in France by protesters expressing their grievance towards China's alleged violation of human rights. In retaliation, Chinese citizens' boycotted products that symbolically represented France (Coombs \& Holladay, 2006; Laufer \& Coombs, 2006). One commonality amongst all these cases is the manner in which organizations became entangled in crisis as a result of ethnic categorization.

Another negative consequence of attributing ethnicity to corporate organizations is the ethnic undertone the crisis often assumes. The situation exercebates if the crisis involves two or more ethnically categorized organizations. Thus, a disagreement between two ethnically categorization organizations can evolve into 
ethnic group rivalry as was the case between Guaranty Trust Bank (perceived as a 'Yoruba' bank) and Innoson Group Limited (perceived as an 'Igbo' organization) (MASSOB, 2017).

In the aforementioned cases, these organizations experienced what this study terms as ethnic attribution crisis, i.e. a crisis an organization experiences as a result of the ethnicity attributed to it by stakeholders. It is important to note that in an ethnic attribution crisis, stakeholders' perception of the crisis and attributions of blame are not based solely on the factors of stability, locus, controllability, severity of damage, prior history, reputation, or performance history of organizations as enumerated by Weiner (1986) and Coomb (1995). Rather, attributions of blame are a factor of the ethnic categorization of the organizations involved the crisis. Behaviours of stakeholders during ethnic attribution crisis is governed by the principle of ingroup favouritism and out-group discrimination espoused in Tajfel \& Turner's (1979) social identity theory. Hence, ethnically categorized organizations receive lower attributions of blame from members of the group and higher attributions of blame from members of the out-group regardless of the cause of the crisis. The idea that stakeholders emotionally decide to favour or support organisations they regard as members of their ethnic group (Turner et al., 1987; Abrams \& Hogg, 1990), but discriminate organizations unaffiliated to their ethni group during a crisis, forms the core of ethnic attribution crisis.

Thus, this study hinges its understanding of ethnic attribution crisis on three notions: 1) that ethnic attribution crisis is an outcome of the ethnic categorization an organization; 2) inter-organizational crisis between ethnically categorised organizations will often have an ethnic undertone and result to rivalry between the ethnic groups involved, and 3) that during an ethnic attribution crisis, stakeholders assign higher attributions of blame to organizations they perceive to be the out-group, and lower attributions of blame to organizations perceived as the in-group members. As an illustration to the first assumption, organizations with a large percentage of a particular nationality or ethnicity within its ownership, board and staff, can consequently be categorized by a national or ethnic identity (e.g. MTN and GTBank). An analogy to the second assumption would be an inter-organizational dispute between organizations X (ethnically categorised as ethnic group A) and organization Y (ethnically categorised as ethnic group B). Disputes between $\mathrm{X}$ and $\mathrm{Y}$ may assume an ethnic undertone. For the third notion, the "ethnicization" of interorganizational crisis between ethnically categorized, could result in members of the ethnic group ' $A$ ' supporting organization ' $\mathrm{X}$ ' and attributing less blame to it whilst discriminating against organization ' $\mathrm{Y}$ ' by attributing higher levels of blame during crisis.

Based on these notions, this study asks the following research questions:

1. Do stakeholders and other members of the Nigerian society attribute ethnicity to corporate organizations in Nigeria?

2. Will there be a significant relationship between stakeholders' ethnic inclination and ethnic categorization of corporate organizations?

3. Are there factors responsible for ethnic categorization?

4. Do crisis involving ethnically categorized organizations assume an ethnic undertone?

5. Will there be a relationship between an organizations ethnic categorization and ethnic attribution crisis?

\section{THEORETICAL FRAMEWORK AND RESEARCH HYPOTHESES}

A combination of Social Identity, Attribution and Situational Crisis Communications (SCCT) theories are utilized in this study to explain stakeholders' categorization of corporate orgnaizations into ethnic groups (social identity theory), and attibutions of blame and crisis responsibility during crisis (attribution and situational crisis communications theories). The theoretical postulations of SCCT and attribution theory, while accounting for the attribution of blame arising from technical or human errors, stability, locus of causality, controllability, severity of damage, organizational reputation, and prior history of the organization (Weiner, 1986; Coombs, 1995), fail to cater for attributions of blame that arise as a result of the ethnic categorization. This study therefore submits an ethnic attribution model to organizational crisis in a multi-ethnic setting. 
Literature in cognitive social psychology recommend the use of subjective reality, rather than objective reality, to make sense about the world of work, employee decision making, and stakeholder image of organizations (Markus \& Kitayama, 1994; Zajonc \& Markus, 1982). This viewpoint prioritizes the 'cognitive social structure' of organizations (Krackhardt, 1987). It argues that perceptions be treated not as errors or inaccuracies since they are real in their consequences on other individuals and organizations. In this study, stakeholders' perceptions of corporate organizations are investigated regardless of whether it confirms with actual reality. For instance, stakeholders might indicate ethnic categorizations amongst organizations or ethnic undertones in organizational crisis. Whether this is accurate is not the goal of this research, rather the perception of corporate organizations and its implications on organizational crisis remain the focus of this study.

\section{Ethnic Categorization of Corporate Organizations \\ Social Identity Theory}

Social identity theory is primarily concerned with group memberships and affiliations. It explains the basic human inclination to categorize and identify with groups similar to oneself, viewing the self as a member of certain groups (in-group) as opposed to other groups (out-group), and how this singular perception creates a bias favorable to members of the in-group and discriminatory towards members of the outgroup. The theory is built on the premise that the self can be categorized in relation to existing social groups through a process of social categorization (Turner et al., 1987) and that, individuals feel a strong sense of belonging (knowledge of and identification with) towards social groups of shared similarities and common identities.Furthermore, it perceives the self as a member of the same social category but distinguishable from other categories, using a social comparison process (Hogg \& Abrams, 1998; Turner et al., 1987). These intricate processes (social categorization \& social comparison) in the formation of social identity result in varying consequences for the self. Social categorization amplifies perceived similarities between the self and in-group members and the differences between self and outgroups. Social comparison applies a selective procedure to amplify the effect of the social categorization process, by focusing on comparisons that enhance favourable outcomes for the self (Stets \& Burke, 2000). Tajfel (1979) observed that in order to protect the social standing of the group, members shield each other from blame by favouring the in-group and attributing blame to the outgroup.

It is important to note that the social categories that the self applies these processes to, are part of a structured society, existing to the individual as power dynamics between contrasting categories (Hogg \& Abrams, 1998; Stets \& Burke, 2000) e.g. Christian vs Muslim (religious), Igbo vs Hausa (ethnic), Black vs White (racial), Democrats vs Republicans (political), Male vs Female (gender-based). The fact that individuals are born into already existing social categories indicates the precedence these categories take over individuals, and that an individual's sense of identity is derived from the social categories they are born into, with meanings conveyed by a structured society (McCall \& Simmons, 1978). As adulthood sets in and individuals gradually enter the world of work, social categorization and social comparison process is continued, forming work groups with ethnic homophilic relationships (Lee \& Reade, 2015).

In plural societies individuals create social identities by identifying with ethnic groups of similar features, behaving like group members, and perceivng the world around via the dominant perspective of the group (Stet \& Burke, 2000). This subjugation of individual views by the collective perspective of the group, forms the basis of social identity within ethnic groups. Amongst cognitive manifestations can be found social stereotyping of groups and their members, i.e. the generalization of stereotyped perceptions to group members. Phrases like "Blacks are violent", "Whites are racists", "Muslims are terrorists", "Igbos love money", "Hausas dislike western education", "South Africans are Xenophobic" are examples of stereotypical labels ascribed to out-group members. Using the social comparison process (Turner et al., 1987, Hoggs \& Abram, 1988), individuals tend to form positive perceptions of the in-group ("Igbo girls are pretty", "Yoruba's are hospitable", "Hausa's have integrity", "Christians are tolerant") while attributing negative stereotypess to outgroups (Stet \& Burke, 2000). Examples of the collective action of members in a group abound in multiracial and multi-ethnic societies, especially during group conflicts and competitions for ethnic dominance. For instance, religious and ethnic conflicts often instigate irrational behavious from 
group behaviors from group members across several countries, indicating a bond within the group across borders. Democratic elections in multi-cultural societies are indicators of competitive collective behavior. The ex-President of the United States, Barrack Obama, received a greater percentage of votes from the African American population, similar to Hilary Clinton who polled more votes from women (Clement, Guskin, Alcantara, \& Esteban, 2016). Studies found deeper participation in the group's culture, closer affiliation with group members, behavioral attractions to the group and differentiation from outgroups, amongst individuals who describe themselves using group labels (Ethier \& Deaux, 1994; Ullah, 1987).

In multi-ethnic societies, it is likely that stakeholders perceive organizations through an ethnic frame or assign ethnic labels to them such that, these organizations become ethnically categorized. Furthermore, individuals with high ethnic consciousness categorize corporations by finding ethnic similarities with certain organizations and differences with others. Going by these assertions, the study hypothesizes the following:

H1: Stakeholders will assign ethnic labels to some corporate organizations operating in Nigeria.

H2: There will be a relationship between stakeholders' ethnic inclinations (consciousness/ identity/ affiliation) and stakeholders' perceptions of ethnic categorization amongst corporate organizations in Nigeria.

H3: Stakeholders and other members of the Nigerian society will indicate organizational factors such as the failure to ethnically diversify workforce, to be responsible for the ethnic categorization of corporate organizations.

\section{Stakeholder Perception of Organizational Crisis \& Attributions of Blame} Attribution Theory \& Situational Crisis Communications Theory

Amongst the several postulations in crisis management literature, Attribution theory (AT) and Situational Crisis Communication theory (SCCT) stand out for the theoretical framework they provide for understanding stakeholder perception of crisis and the attribution of blame to organizations during crisis. Stakeholders want to know the cause of any crisis and whether it could have been prevented (Coombs \& Holladay, 2010). Thus, they carry out a ratiocination process to find out whether the crisis was caused by technical or human errors (Weiner, 1986). Crisis that occur as a result of technical errors reduces the blame attributed to the organization, while human error generated crisis increases the attributions of blame for the organization.

Weiner (1986) indicates three primary factors involved in stakeholders' ratiocination process of the crisis- stability, locus, and controllability. The factor of stability refers to the frequency of the cause of crisis as opposed to its rarity. When the cause of the crisis is rather frequent, attributions of blame tend to be higher. The locus factor implies the position of the cause of crisis, i.e. whether the cause of the crisis was within the organization's control (internal locus) or outside of it (external locus). Financial misappropriation, and product tampering, are some examples of internal locus while natural disasters, acts of terrorism are but a few examples of external locus of control. Crisis that occur as a result of internal locus receive higher attributions of blame compared to those arising from external factors (Weiner, 1986). Controllability is similar to the locus factor, in the sense that controlling the events causing the crisis could be internal or external. Similarities between the locus and controllability factors have led studies to refer to both factors as intentionality of the act (Coombs, 1995, 1998; Coombs \& Holladay, 1996; Coombs \& Rybacki, 1999).

Coombs (1995) built on Weiner's attribution theory to include organizational reputation and crisis type as additional factors for determining attribution of blame. He introduced the concept of 'crisis responsibility' to mean the extent to which organizations are blamed for a crisis. SCCT posits three factors for evaluating crisis responsibility: attribution of control, severity of damage, and performance history (Coombs, 1998). 
All things being equal, it seems logical for the attribution of blame to be based on the objective measures of stability, locus, controllability, severity of damage and organizational reputation. However, this study submits that in a plural society, these factors do not provide sufficient understanding for attribution of crisis responsibility. It posits that attributions of blame is also a function of organizational ethnic categorization and that such categorizations, could lead to the emergence of ethnic undertones during the crisis.

Thus, the following hypothetical statements are made:

H4: Stakeholders and other members of the Nigerian society will report perceived ethnic undertones in crises involving ethnically categorized organizations.

H5: A relationship will be found to exist between stakeholder perceived ethnic categorization of corporate organizations and the perception of ethnic attributed organizational crisis by stakeholders?

A confirmation of the study's hypotheses would reveal ethnic undertones in crisis involving ethnically categorized organizations operating in multi-ethnic environments. Furthermore, it would validate the proposed framework for understanding ethnic attribution crisis in a multi-ethnic society. Figure 1 portrays the ethnic attribution framework guiding this study and proposes factors (i.e. individual and organizational) responsible for the ethnic categorization of organizations.

FIGURE 1

\section{PROPOSED ETHNIC ATTRIBUTION FRAMEWORK}

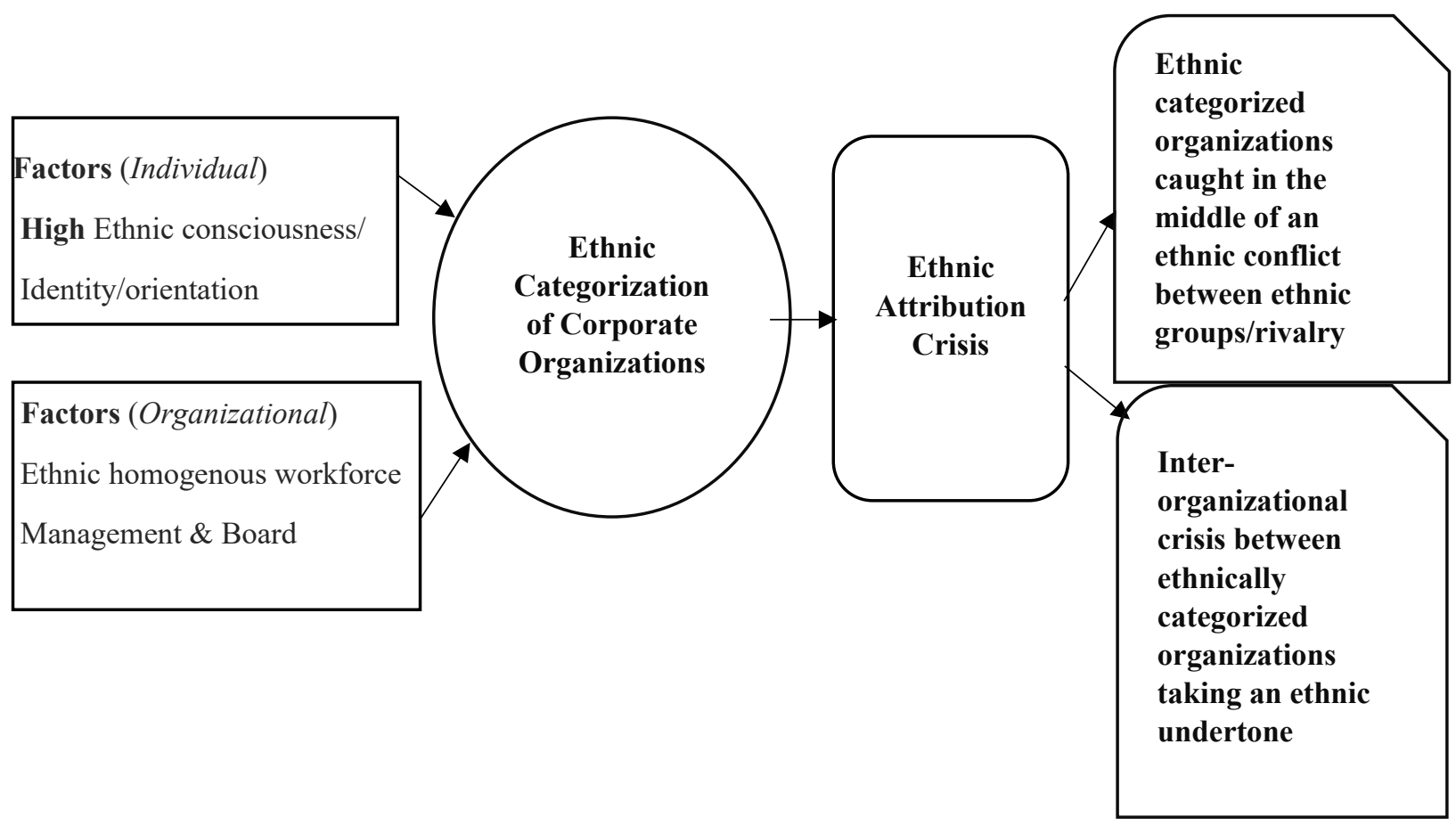

\section{METHODS}

\section{Design}

The study utilizes a quantitative research design with the aid of survey technique, carried out online, to gather information subject to statistical analysis and hypothesis testing. This seemed most appropriate considering the nature of the research questions and statements of hypotheses. 


\section{Sample Techniques \& Procedure}

The challenges caused by the COVID 19 virus in terms of restrictions on movement and 'lockdowns', obstructed plans to apply probability sampling techniques in the selection of a representative sample. As a result, getting respondents willing to physically participate in the survey proved difficult. Thus, improvisations were made via the use of online platforms in the selection of sample participants and the distribution of data instruments.

Non-probability sampling techniques (convenient and snowball) were used to generate sample for this study. Links to online copies of the questionnaire were advertised on social media platforms- Twitter and Facebook. These platforms have become the hub of intellectual, social, and political engagements for today's young and middle-aged Nigerians from different ethnic groups. Ethnic themed crisis and secessionist agitations have laid claims on these platforms, granting users the opportunity to identify with ethnic groups. Thus, it is expected that the crop of social media users on Twitter and Facebook would be ethnically conscious and give adequate responses to the survey questions. After three weeks of data collation, submissions were discontinued and a total of 158 responses were recorded.

TABLE 1

DEMOGRAPHIC INFORMATION OF STUDY PARTICIPANTS

\begin{tabular}{ccc}
\hline Variables & Values & Percentage Count \\
Gender & Male & $51 \%$ \\
& Female & $49 \%$ \\
Age Group & $21-30$ & $20 \%$ \\
& $31-40$ & $35.50 \%$ \\
& $41-50$ & $33.50 \%$ \\
Religion & $51-60$ & $11 \%$ \\
& & \\
Ethnic Group & Christian & $62 \%$ \\
& Moslem & $38 \%$ \\
& Igbo & $16.80 \%$ \\
& Yoruba & $21.90 \%$ \\
& Hausa & $16.80 \%$ \\
& Ijaw & $1.90 \%$ \\
& Efik & $4.50 \%$ \\
& Tiv & $3.20 \%$ \\
& Igala & $3.20 \%$ \\
& Esan & $3.20 \%$ \\
& Kanuri & $4.50 \%$ \\
& Itsekiri & $5.20 \%$ \\
& Ibibio & $4.50 \%$ \\
& Benin & $4.50 \%$ \\
& Ibara & $1.90 \%$ \\
& Fulani & $3.20 \%$ \\
& Urhobo & $2.60 \%$ \\
& Nupe & $1.90 \%$ \\
\hline
\end{tabular}

As can be seen from table above, only sixteen (16) ethnic groups were represented in the sample, with majority of participants belonging to the 3 major ethnic groups in Nigeria. This was due to the difficulty in randomly sampling equal number of participants from all ethnic groups in the country using an online data 
collection platform. The use of convenient and snowball sampling techniques did not guarantee equal representation of all ethnic groups. Table 1 shows the Yoruba ethnic group to have the highest number of participants $(21.9 \%)$, while the Igbo and Hausa ethnic groups had equal representation (16.8\% each). Minority ethnic groups (Ijaw, Efik, Tiv, Igala, Esan, Kanuri, Itsekiri, Ibibio, Benin, Ibara, Fulani, Urhobo, and Nupe) made up $44.5 \%$ of the sample.

\section{Measure}

A 22-item questionnaire was developed to measure stakeholder perception of ethnic inclinations (identity/consciousness/group affiliation), and perceived ethnic categorization of corporate organizations in Nigeria. The questionnaire comprised two sections: the first required respondents to reveal demographic information while the second section elicited participant responses with relation to study variables. The latter consisted of 22 items measuring the extent to which stakeholders identified with, are conscious of, and affiliated to their ethnic groups (ethnic inclination) as well as the extent to which stakeholders indicated ethnic categorizations amongst corporate organizations (perceived ethnic categorization) and the extent to which stakeholders perceived ethnic undertones in crisis involving ethnically categorized organizations (perceived ethnic attribution crisis). A 4-point Likert scale was used to gather responses, ranging from strongly disagree (1) to strongly agree (4). For validation purposes, the questionnaire was shown to 3 independent researchers to assess the extent to which the items measure study variables. All three affirmed the validity of these items. Reliability analysis revealed all 22 items to have a Cronbach alpha of .91, indicating the measure to be statistically reliable.

\section{Perceived Ethnic Identity/Consciousness/Group Affiliation}

The first seven (7) items asked participants about perceptions of ethnic consciousness, support for ingroup and discrimination against outgroups especially during conflict. Using a 4-point Likert format, responses were totaled to give a composite score for each participant, with high scores indicating high perception of ethnic inclinations- consciousness, group identification, in-group favoritism/outgroup discrimination and ethnocentric tendencies. A mean score of 19.8 revealed a high ethnic consciousness and strong group identification amongst participants. Cronbach alpha for all seven items was found to be .86, a high reliability index.

\section{Perceived Ethnic Categorization of Organizations}

Items 8-14 elicited participants' responses with regards to perceptions of ethnic categorization of organizations. Higher composite scores denoted possible categorization of organizations. Participants' mean score was found to be high (21.2) indicating stakeholders' perceptions of ethnic categorization. The reliability index was found to be .83 (Cronbach alpha).

\section{Perceived Ethnic Attribution Crisis}

The last eight (8) items measure the extent to which stakeholders attribute ethnicity to organizational crisis and perceive ethnic undertones in crisis involving categorized organizations. As with previously mentioned composite scores, higher scores reveal a higher perception of ethnic attribution crisis. Mean calculation for total scores revealed a high mean score (25.3), while statistical reliability analysis showed all eight items to have a Cronbach alpha of .79.

\section{Data Entry and Analysis}

Participant responses were coded into a statistical package software (SPSS version 20) for descriptive and inferential statistics. Percentage Counts and Pearson Product Moment Correlation were used to test study hypotheses. 


\section{RESULTS}

Perceived Ethnic Categorization of Corporate Organizations

Hypothesis 1: Stakeholders and Other Members of the Nigerian Society Will Attribute Ethnicity or Assign Ethnic Labels to Some Corporate Organizations Operating in Nigeria

The percentage figures of participants' responses to items measuring the perceived attribution of ethnicity to corporate organizations are reported in Table 2 below.

\section{TABLE 2 \\ DESCRIPTIVE STATISTICS OF ITEMS MEASURING ETHNIC CATEGORIZED PERCEPTION OF ORGANIZATIONS}

\begin{tabular}{lcccc}
\hline \multicolumn{1}{c}{ Items } & $\begin{array}{c}\text { Strongly } \\
\text { Disagree }\end{array}$ & Disagree & Agree & $\begin{array}{c}\text { Strongly } \\
\text { Agree }\end{array}$ \\
$\begin{array}{l}\text { There are corporate organizations in Nigeria that } \\
\text { can be classified as belonging to an ethnic group? }\end{array}$ & $1.30 \%$ & $8.90 \%$ & $63.90 \%$ & $25.90 \%$ \\
$\begin{array}{l}\text { When I see some corporate organizations in } \\
\text { Nigeria, I easily assign them to ethnic groups in my } \\
\text { head? }\end{array}$ & $13.30 \%$ & $28.50 \%$ & $41.10 \%$ & $17.10 \%$ \\
$\begin{array}{l}\text { Because we are ethnically conscious, we tend to } \\
\text { view even corporate organizations through the lens } \\
\text { of ethnicity? }\end{array}$ & $1.90 \%$ & $10.80 \%$ & $62 \%$ & $25.30 \%$ \\
$\begin{array}{l}\text { Ethnicity is such a strong factor in Nigeria that } \\
\text { organizations are often viewed along ethnic lines }\end{array}$ & $1.90 \%$ & $10.80 \%$ & $58.90 \%$ & $28.50 \%$ \\
\hline
\end{tabular}

The table reveals over half of the participants concurring to all four items, thereby affirming stakeholders' perceptions of ethnic categorization amongst corporate organizations. Approximately $90 \%$ (sum of agree and strongly agree percentage figures) believe corporate organizations can be classified as belonging to an ethnic group, while $58 \%$ admit to assigning corporate organizations to ethnic groups, and $87 \%$ are of the opinion organizations tend to be viewed along ethnic lines as a result of Nigeria's high ethnic consciousness. This same percentage of participants ( $87 \%)$ were also in accord with the notion of corporate organizations being grouped into ethnic categories. These results thus fail to reject the first hypothesis as they affirm stakeholders' attribution of ethnicity to corporate organizations.

More importantly, the finding asserts the use of ethnic frames in the perception of corporate organizations operating in plural societies. Such environments increase the tendency to view social institutions, corporate organizations inclusive, through an ethnic lens.

Hypothesis 2: There Will Be a Relationship Between Stakeholders Perceived Ethnic Inclinations and Stakeholders' Categorization of Corporate Organizations in Nigeria

Composite scores (sum of participants' responses to items measuring both variables) were used to determine the extent to which a relationship exists between these variables.

TABLE 3

CORRELATION STATISTICS BETWEEN ETHNIC INCLINATION \& ETHNIC CATEGORIZATION (PEARSON)

\begin{tabular}{lcc}
\hline & Variables & Perceived Ethnic Categorization \\
& Perceived Ethnic Inclinations & $.53 * *$ \\
\hline$* * p<.01$ & &
\end{tabular}


A significant relationship between ethnic inclinations and ethnic categorization of organizations was found $(\mathrm{r}=.53, \mathrm{p}<.01)$, indicating the pattern of relationship between these two variables to be positively linear- an increase in perceptions of ethnic consciousness, result to an increase in perceptions of ethnic categorization. This study, therefore, fails to reject its second hypothesis.

\section{Hypothesis 3: Stakeholders Will Indicate the Failure to Ethnically Diversify Staff as Being Responsible} for Ethnic Categorization of Organizations

To test the third hypothesis, stakeholders' opinions regarding organizational factors responsible for perceptions of ethnic categorization were assessed through certain items. One of the items sought to know whether participants ascribe ethnicity to corporate organizations due to external factors, while the other asked if absence of ethnic diversity at work contributes to organizational ethnic categorization. Responses to these items are presented in Table 4.

TABLE 4

ORGANIZATIONAL (EXTERNAL) FACTORS OF ETHNIC CATEGORIZATION

\begin{tabular}{|c|c|c|c|c|}
\hline Items & $\begin{array}{l}\text { Strongly } \\
\text { Disagree }\end{array}$ & Disagree & Agree & $\begin{array}{c}\text { Strongly } \\
\text { Agree }\end{array}$ \\
\hline $\begin{array}{l}\text { Certain corporate organizations in Nigeria due to external } \\
\text { factors have ethnic labels attached to them such that they are } \\
\text { categorized as belonging to a particular ethnic group? }\end{array}$ & $2.5 \%$ & $10.8 \%$ & $64.6 \%$ & $22.2 \%$ \\
\hline $\begin{array}{l}\text { Organizations in Nigeria that fail to diversify their staff, } \\
\text { management and board run the risk of being perceived as } \\
\text { belonging or supporting an ethnic group? }\end{array}$ & $1.3 \%$ & $7.6 \%$ & $60.1 \%$ & $31 \%$ \\
\hline
\end{tabular}

Approximately $90 \%$ of respondents felt organizations have ethnic labels attached to them as a result of external factors; that is, factors emanating from the organization. On whether organizations ran the risk of being perceived as belonging to ethnic groups when they fail to ethnically diversify their workforce, $80 \%$ of the respondents concurred. Hence, the study fails to reject the third hypothesis, as stakeholders in this study were found to indicate external (organizational) factors, such as failure to ethnically diversify staff as a contributing factor for ethnic categorization.

\section{Perceived Ethnic Attribution Crisis}

Hypothesis 4: Stakeholders and Other Members of the Nigerian Society Will Report Perceived Ethnic Undertones in Inter-Organizational Crises Involving Ethnically Categorized Organizations

In testing the fourth hypothesis, stakeholders were required to indicate levels of disagreement or agreement in relation to questions around ethnic undertones ariing during crisis between categorized organizations. The crisis between Guaranty Trust Bank and Innoson Group Limited was used as a reference point. Responses are detailed in Table 5. 


\section{TABLE 5 \\ DESCRIPTIVE STATISTICS FOR ETHNIC UNDERTONES DURING INTER-ORGANIZATIONAL CRISIS}

\begin{tabular}{|c|c|c|c|c|}
\hline Items & $\begin{array}{l}\text { Strongly } \\
\text { Disagree }\end{array}$ & Disagree & Agree & $\begin{array}{c}\text { Strongly } \\
\text { Agree }\end{array}$ \\
\hline $\begin{array}{l}\text { If an organization that I perceive as belonging to my ethnic } \\
\text { group is in a crisis with another organization belonging to } \\
\text { another ethnic group, I will see the crisis as an ethnic rivalry }\end{array}$ & $3.2 \%$ & $8.2 \%$ & $67.1 \%$ & $21.5 \%$ \\
\hline $\begin{array}{l}\text { I would gladly support an organization that represents my } \\
\text { ethnic group if it's in a crisis with an organization from } \\
\text { another ethnic group, regardless of who is to blame? }\end{array}$ & 5.1 & $25.3 \%$ & $46.2 \%$ & $23.4 \%$ \\
\hline $\begin{array}{l}\text { During the GTBank/Innoson crisis, most people interpreted } \\
\text { it to be a crisis between a Yoruba bank and an Igbo auto } \\
\text { company because they saw them as such? }\end{array}$ & $1.3 \%$ & $1.9 \%$ & $55.7 \%$ & $41.1 \%$ \\
\hline $\begin{array}{l}\text { Nigerians ascribe ethnic undertones to crisis involving } \\
\text { categorized organizations because we like to apply the } \\
\text { 'ethnic card' to everything, even an inter-organizational } \\
\text { crisis? }\end{array}$ & $1.3 \%$ & $4.4 \%$ & $67.1 \%$ & $27.2 \%$ \\
\hline $\begin{array}{l}\text { Ethnicity is a strong factor Nigerians use in the evaluation } \\
\text { of a crisis, in showing support for or attributing blame to } \\
\text { corporate organizations during inter-organizational crisis? }\end{array}$ & $1.3 \%$ & $6.3 \%$ & $52.5 \%$ & $39.9 \%$ \\
\hline
\end{tabular}

The results displayed in Table 5 reveal a high percentage of the sample agreeing and strongly agreeing to all items on perceptions of ethnic attributed organizational crisis. Slightly over $88 \%$ report they would view a crisis between categorized organizations as an ethnic rivalry, while $69.6 \%$ would gladly support an organization that represents their ethnic group if it was ever in a crisis with an organization from another ethnic groups, regardless of the cause of the crisis. Using the GTBank/Innoson crisis, a very high percentage (96.8\%) of respondents concurred with the notion that most people interpreted the crisis as a Yoruba bank/Igbo automobile conflict. Equally, high percentages were recorded of respondents opining that Nigerians ascribed ethnic undertones to the crisis between organizations (94.3\%), and concurred with the use of ethnicity in the evaluation of a crisis and the attributions of favor or blame (92.4\%).

The large percentage of concurrence on all items measuring stakeholders' perceptions of ethnic undertones in crisis involving categorized organizations, implies a failure to reject the fourth hypothesis. Stakeholders in this study reported perceived ethnic undertones in actual crisis involving ethnically perceived organizations (e.g., GTBank/Innoson) or intentions to perceive ethnic undertones in hypothetical crises situations. However, these percentage counts do not suffice in determining the extent to which perceived ethnic categorization of corporate organizations significantly relates to perceptions of ethnic attribution crisis. A test of the final hypothesis fills this lacuna.

Hypothesis 5: A Relationship Will Be Found to Exist Between Ethnically Categorized Organizations and the Perceptions of Ethnic Attribution Crisis During Inter-Organizational Crisis

A Pearson Product Moment Correlation was executed, testing the possible relationship between the composite scores of the items measuring perceptions of ethnic categorization and ethnic attribution crisis. Result is displayed on Table 6 below. 


\title{
TABLE 6 \\ CORRELATION STATISTICS BETWEEN ETHNIC CATEGORIZATION \& ETHNIC ATTRIBUTED ORGANIZATIONAL CRISIS (PEARSON)
}

\author{
Variables \\ Perceived Ethnic Categorization \\ Perceived Ethnic Attributed Organizational Crisis
}

$.72 *$

${ }^{*} p<.001$

The relationship between perceptions of ethnic categorization and ethnic attribution crisis was found to be positively significant $(\mathrm{r}=.72, \mathrm{p}<.001)$. That is, an increase in the composite scores of participants' perceptions of ethnic categorization significantly relates to an increase in participants' scores on perceptions of ethnic attribution crisis. As with the other hypothetical statements, this study fails to reject the fifth hypothesis.

\section{DISCUSSION AND IMPLICATIONS}

This study sought to present an ethnic attribution perspective to organizational crisis in multi-ethnic societies by suggesting the inclusion of ethnicity in understanding stakeholder's perception of organizations and how they attribute blame to organizations during crisis. It proposed an ethnic attribution framework built on the notion that in multi-ethnic societies, the tendency to perceive organizations via an ethnic frame is high. Results revealed a large percentage of the study's sample reporting the use of ethnic labels in categorizing corporate organizations along ethnic lines (e.g., Yoruba bank, Igbo firm, Hausa company etc.).

In plural societies, individuals create social identities by identifying with ethnic groups they feel share similar traits with themselves. Seeing that organizations are in themselves, groups of individuals, it is likely, the social categorization process is extended to corporate entities as well. Organizations therefore must understand that ethnicity, being both a cognitive and group phenomenon (Le Vine, 1999), possesses the capacity to wield strong influence over perceptions of stakeholders. The ascription of ethnic labels to organizations, constitutes one of the cognitive outcomes of strong identification with ethnic groups. Thus, in identifying with an ethnic group, chances are that individuals within the group imbibe the collective mentality of the group and perceive organizations through the dominant perspective of the group. If the group collectively perceives an organization as part of the group, members will inculcate such perception, and act accordingly.

This study also found a positively significant relationship to exist between stakeholders' ethnic inclinations and organizational ethnic categorization. That is, individuals who reported strong identification with ethnic groups, reported strong inclinations for ethnically categorizing organizations. From an organizational perspective, the logic of this notion led the current study to insinuate a plausible connection between ethnic inclinations and the tendency to ethnically categorize an organization. Thus, it proposed a framework for explaining the relationship between intrinsic factors within the individual and the individual's ethnic perception of corporate organizations (see Figure 1). The finding that perceived ethnic inclination is positively related to perceived ethnic categorization validates the first link of the study's ethnic attribution framework and implies that individual ethnic biases fuel societal ethnic categorizations of corporate organizations.

In addition, the study also found large percentages of its respondents affirming the influence of organizational factors like the lack of ethnic diversity within an organization as a contributing factor for ethnic categorization. In plural societies like Nigeria, there is a tendency for stakeholder's to categorize an organization based on the preponderant ethnicity of its workforce. Though this finding affirms the validity of the second link in this study's proposed ethnic attribution framework, the researcher admits to the use of only percentage counts in finding out the opinion of stakeholders vis-à-vis organizational factors responsible for ethnic categorization. The width of the margin between the number of stakeholders 
concurring and disagreeing with this notion does not eliminate the pitfalls of conclusions drawn from solely descriptive statistical analysis.

Lastly, the study submitted certain notions for understanding ethnic attribution crisis, one of which was the assumption that inter-organizational crisis between ethnically categorized organizations assume an ethnic undertone. As shown in Table 5, high percentage counts were observed for all items eliciting responses on stakeholder perceptions of ethnic undertones in the crisis between ethnic labeled organizations.

The ethnic attribution framework proposed in this study was also hinged on the notion that ethnic attribution crisis in multi-ethnic societies is a function of the attribution of ethnicity to corporate organizations. To test this, it was hypothesized that a significant relationship will be found between ethnic categorization of corporate organizations and ethnic undertones in organizational crisis. Correlation statistics indicated positive relationship between both variables, thereby completing the final link in the proposed framework. The study finds a deepening in ethnic perceptions about corporate organizations to result in higher attributions of ethnicity during crisis involving same organization(s), and subsequently the attribution of favour or blame to the organization(s) by stakeholders from varying ethnic groups. This finding helps put in perspective the rationale for mob attacks unleashed on South African firms (MTN Nigeria and Shoprite) operating in Nigeria in 2019 as a result of xenophobic attacks on Nigerians living in South Africa.

In a bid to fill this gap, this article interrogated the assumption that the societal ethnic context in which organizations operate influence organizational crisis in ways yet to be studied. Its findings showed the instrumentality of ethnic identity in shaping perceptions of organizational crisis in multi-cultural societies.

\section{IMPLICATIONS \& STUDY RECOMMENDATIONS}

Amongst the numerous implications of this study's findings is the substantiation of the constructivist view that corporations acquire an ethnic identity through a social process. Ethnicity as a social construct evolves and changes over time, therefore, ethnic perceptions about corporate organizations can also evolve and be changed over time. There is therefore a need for corporate communications managers to evaluate the perceptions of their stakeholders about their organizations.

For a while, crisis management literature has been devoid of studies targeted at the effects of organizational ethnic categorization on organizational crisis outcomes as it lacked adequate frameworks for understanding social context on organizational crisis. It is important that crisis managers in multi-ethnic societies incorporate an ethnic strategy into their crisis management framework. The salience of ethnicity in an ethnocentric society like Nigeria, makes it a potential trigger for escalating organizational crisis. Thus, amongst potential threats to crisis enlisted in an organization's crisis prevention plan, the weaponization of ethnic identity should be included.

\section{FUTURE RESEARCH}

While this paper has broadened the understanding of organizational crisis in multi-cultural societies, there is however much to be done to in building and developing several of the assumptions suggested in the ethnic attribution framework. Firstly, an in-depth investigation of organizational factors influencing ethnic categorization of organizations need to be carried out. The current study finds the lack of ethnic diversity amongst staff as a contributing factor. Future studies need to probe further to find out more factors responsible for ethnic categorization.

\section{ACKNOWLEDGEMENTS}

Special thanks to my wife, Gertrude Nwagboh, whose support led to the development of this paper, and to Craig, Nicole and Jason for giving me all the joy in the world. 


\section{REFERENCES}

Abrams, D., \& Hogg, M.A. (1990). Social identification, self-categorization and social influence. European Review of Social Psychology, 1(1), 195-228. https://doi.org/10.1080/14792779108401862

Adamson, J., McNatt, R., \& Bray McNatt, R. (2000). The Denny's Story: How a Company in Crisis Resurrected Its Good Name and Reputation. New York: John Wiley.

Angerbrandt, H. (2015). Religion, ethnicity and citizenship: Demands for territorial self-determination in southern Kaduna, Nigeria. Journal of Contemporary African Studies, 33(2), 232-250. https://doi.org/10.1080/02589001.2015.1066081

Baker, G.F. (2001). Race and reputation: Restoring image beyond the crisis. In Handbook of public relations (pp. 513-520). Thousand Oaks, CA: Sage.

Barton, L. (1993). Crisis in organizations: Managing and communicating in the heat of chaos. Cincinnati: South-Western Publishing.

Barton, L. (2001). Crisis in organizations II: Managing and communicating in the heat of crisis (2nd ed.). Cincinnati: College Divisions South-Western.

Brief, A.P., Butz, R.M., \& Deitch, E.A. (2005). Organizations as reflections of their environments: The case of race composition. In R.L. Dipboye \& A. Colella (Eds.), Discrimination at Work: The Psychological and Organizational Bases (pp. 119-148). Mahwah, New Jersey: Lawrence Erlbaum Associates.

Brinson, S.L., \& Benoit, W.B. (1999). The tarnished star: Restoring Texaco's damaged public image. Management Communication Quarterly, 4(12), 483-510.

Bundy, J., \& Pfarrer, M.D. (2015). A burden of responsibility: The role of social approval at the onset of a crisis. Academy of Management Review, 40(3). https://doi.org/10.5465/amr.2013.0027

Bundy, J., Pfarrer, M.D., Short, C.E., \& Coombs, T. (2017). Crises and Crisis Management: Integration, Interpretation, and Research Development. Journal of Management, 43. https://doi.org/10.1177/0149206316680030

Chin, T., Naidu, S., Ringel, J., \& Snipes, W. (1998). Denny's: Communication amidst a discrimination case. Business Communication Quarterly, 1(61), 180-196.

Civelek, M.E., Cemberci, M., \& Eralp, N.E. (2016). The Role of Social Media in Crisis Communication and Crisis Management. International Journal of Research in Business and Social Science (2147-4478), 5(3), 111-120. https://doi.org/10.20525/ijrbs.v5i3.279

Clement, S., Guskin, E., Alcantara, C., \& Esteban, C. (2016). 2016 election exit polls: How the elections has shifted. Retrieved July 28, 2020, from https://www.washingtonpost.com/graphics/politics/2016-election/exit-polls/

Coombs, T. (1995). Choosing the right words: The development of guidelines for the selection of the "appropriate" crisis response strategies. Management Communication Quarterly, (8), 447-476.

Coombs, T. (1998). An Analytic Framework for Crisis Situations: Better Responses From a Better Understanding of the Situation. Journal of Public Relations Research, 10(3), 177-191. https://doi.org/10.1207/s1532754xjprr1003_02

Coombs, T., \& Holladay, S. (1996). Communication and attributions in a crisis: An experimental study in crisis communication. Journal of Public Relations Research, (8), 279-295.

Coombs, T., \& Holladay, S. (2002). Helping crisis managers protect reputational assets: Initial tests of the situational crisis communication theory. Management Communication Quarterly, (16), 165-186.

Coombs, T., \& Holladay, S. (2006). Unpacking the halo effect: Reputation and crisis management. Journal of Communication Management, 10(2), 123-137. https://doi.org/10.1108/13632540610664698

Coombs, T., \& Holladay, S. (2010). The handbook of crisis communication (1st ed.). In J.S. Coombs, W. Timothy, \& Holladay (Eds.). Chichester: Wiley-Blackwell.

Coombs, T., \& Rybacki, K. (1999). Public relations education: Where is pedagogy? Public Relations Review, 25(1), 55-63. https://doi.org/10.1016/S0363-8111(99)80127-1 
Coombs, T., \& Schmidt, L. (2000). An Empirical Analysis of Image Restoration: Texaco's Racism Crisis. Journal of Public Relations Research, 12(2), 163-178. https://doi.org/10.1207/s1532754xjprr1202_2

Ethier, K., \& Deaux, K. (1994). Negotiating social identity when contexts change: Maintaining identification and responding to threat. Journal of Personality and Social Psychology, 67, 243251.

Falkheimer, J., \& Heide, M. (2006). Crisis communicators in change: From plans to improvisations. The Handbook of Crisis Communication, pp. 511-526.

Frandsen, F., \& Johansen, W. (2005). Crisis communication and the rhetorical arena: A multi-vocal approach. Conference on Corporate Communication.

Gephart, R.P. (2007). Crisis sensemaking and the public inquiry. In C.M. Pearson, C. Roux-Dufort, \& J.A. Clair (Eds.), International handbook of organizational crisis management (pp. 123-160). Thousand Oaks, CA: Sage.

Hogg, M.A., \& Abrams, D. (1998). Social identifications: A social psychology of intergroup relations and group processses. London: Routledge.

Hussain, Y., \& Bagguley, P. (2015). Reflexive ethnicities: Crisis, diversity and re-composition. Sociological Research Online, 20(3). https://doi.org/10.5153/sro.3776

Jacques, T. (2009). Issue management as a post-crisis discipline: Identifying and responding to issue impacts beyond the crisis. Journal of Public Affairs, 9, 35-44.

James, E.H., \& Wooten, L.P. (2011). Crisis management: Informing a new leadership research agenda. Academy of Management Journal, 49, 1103-1118.

Johns, G. (2006). The essential impact of context on organizational behavior. Academy of Management Review, 31(2), 386-408.

Kahn, W.A., Barton, M.A., \& Fellows, S. (2013). Organizational crises and the disturbance of relational systems. Academy of Management Review, 38, 377-396.

Kim, J.H. (2004). "They are more like us": The salience of ethnicity in the global workplace of Korean transnational corporations. Ethnic and Racial Studies, 27(1), 69-94. https://doi.org/10.1080/0141987032000147940

Krackhardt, D. (1987). Cognitive social structures. Social Networks, 9(2), 109-134. https://doi.org/10.1016/0378-8733(87)90009-8

Lampel, J., Shamsie, J., \& Shapira, Z. (2009). Experiencing the improbable: Rare events and organizational learning. Organization Science, 20(5), 835-845. https://doi.org/10.1287/orsc.1090.0479

Laufer, D., \& Coombs, W.T. (2006). How should a company respond to a product harm crisis? The role of corporate reputation and consumer-based cues. Business Horizons, 49(5), 379-385. https://doi.org/10.1016/j.bushor.2006.01.002

Lee, B.K. (2005). Hong Kong consumers' evaluation in an airline crash: A path model analysis. Journal of Public Relations Research, 4(174), 363-391.

Lee, H-J. (2016). Diversity at work matters in times of violent ethnic conflicts. Retrieved September 12, 2020, from https://blogs.lse.ac.uk/management/2016/08/12/diversity-at-work-matters-in-times-ofviolent-ethnic-conflicts/

Lee, H-J., \& Reade, C. (2015). Ethnic homophily perceptions as an emergent ihrm challenge: Evidence from firms operating in Sri Lanka during the ethnic conflict. The International Journal of Human Resource Management, 26(13), 1645-1664. https://doi.org/10.1080/09585192.2014.958514

Liu, B.F., \& Pompper, D. (2012). The crisis with no name: Defining the interplay of culture, ethnicity, and race on organizational issues and media outcomes. Journal of Applied Communication Research, 40(2), 127-146. https://doi.org/10.1080/00909882.2012.654499

Liu, W., Lai, C.H., \& Xu, W. (Wayne). (2018). Tweeting about emergency: A semantic network analysis of government organizations' social media messaging during hurricane Harvey. Public Relations Review, 44(5). https://doi.org/10.1016/j.pubrev.2018.10.009 
Markus, H.R., \& Kitayama, S. (1994). The cultural construction of self and emotion: Implications for social behavior. Emotion and Culture: Empirical Studies of Mutual Influence, pp. 89-130. https://doi.org/10.1037/10152-003

MASSOB. (2017). Innoson's arrest, plot to frustrate Igbo businessmen. Retrieved October 30, 2019, from https://punchng.com/innosons-arrest-plot-to-frustrate-igbo-businessmen-massob/

McCall, G.J., \& Simmons, J.L. (1978). Identities and interactions. New York: Free Press.

McKay, P.F., Avery, D.R., Tonidandel, S., Morris, M.A., Hernandez, M., \& Hebl, M.R. (2007). Racial differences in employee retention: Are diversity climate perceptions the key? Personnel Psychology, 60, 35-62.

Nnoli, O. (2008). Ethnic politics in Nigeria. Enugu: SNAAP Press Ltd.

Nwaoga, C.T., Nche, G.C., \& Olihe, A.O. (2014). The national conference, ethno-religious pluralism and the challenge of national unity in Nigeria. Global Journal of Arts, Humanities and Social Sciences, 2(3), 44-58.

Oguntola-Laguda, D. (2008). Religion and politics in a pluralistic society: The Nigerian experience. Politics and Religion, 2(2), 123-133. Retrieved from https://pdfs.semanticscholar.org/a219/656c74c610af05c7dbcc663b68dfa7b766ed.pdf

Okolie, A.C. (2003). The appropriation of difference: state and the construction of ethnic identities in nigeria. Identity, 3(1), 67-92. https://doi.org/10.1207/s1532706xid0301_05

Osaghae, E.E. (1995). Structural adjustment and ethnicity in Nigeria. Uppsala: Nordic African Institute.

Owede, C., Rasheed, S., \& Arunah, M. (2016). Exploring Nigeria's ethno-religious diversities for an enduring national unity: The perception of teachers in Bayelsa state. Nigerian Journal of Social Studies, 21(1), 60-74.

Peacock, W.G., \& Ragsdale, K.S. (1998). Social systems, ecological networks and disasters. In W.P. Peacock, B.H. Morrow, \& H. Galdwin (Eds.), Hurricane Andrew: Ethnicity, gender and the sociology of disasters (pp. 20-34). New York: Routledge.

Pearson, C.M., \& Clair, J.A. (1998). Reframing crisis management. Academy of Management Review, 23, $59-76$.

Pearson, C.M., Roux-Dufort, C., \& Clair, J.A. (2007). International handbook of organizational crisis management. https://doi.org/10.4135/9781412982757

Perrow, C. (1984). Normal accidents: Living with high-risk technologies. New York: Basic.

Pugh, S.D., Dietz, J., Brief, A.P., \& Wiley, J.W. (2008). Looking inside and out: The impact of employee and community demographic composition on organizational diversity climate. Journal of Applied Psychology, 93(6), 1422-1428. https://doi.org/10.1037/a0012696

Roux-Dufort, C. (2007). Is crisis management (only) a management of exceptions? Journal of Contingencies and Crisis Management, 15, 105-114.

Stets, J.E., \& Burke, P.J. (2000). Identity theory and social identity theory. Social Psychology Quarterly, 63(3), 224-237. https://doi.org/10.2307/2695870

Tajfel, H., \& Turner, J. (1979). An integrative theory of intergroup conflict. In W.G. Austin \& S. Worchel (Eds.), The social psychology of intergroup relations (pp. 33-47). Monterey, CA: Brooks/Cole.

Taylor, M., Coombs, W.T., \& Holladay, S.J. (1995). Organizational use of new communication technology in product recall crises communicating about crisis through technology. Hearit. Retrieved from https://engage.purdue.edu/learn/pluginfile.php/71764/mod_page/content/20/ Handbook of Crisis Com\%252c Ch. 20.pdf

Trager, L. (2001). Yoruba hometowns: Community, identity and development in Nigeria. Ibadan: Spectrum.

Turner, J., Hogg, M.A., Oakes, P.J., Reicher, S.D., \& Wetherell, M.S. (1987). Rediscovering the social group: A self-categorization theory. Oxford, UK: Blackwell.

Ukiwo, U. (2005). The study of ethnicity in Nigeria. Oxford Development Studies, 33(1), 7-23. https://doi.org/10.1080/13600810500099592

Ullah, P. (1987). Self-definition and psychological group formation in an ethnic minority. British Journal of Social Psychology, 26, 17-23. 
Ulmer, R.R., Sellnow, T.L., \& Seeger, M.W. (2015). Effective crisis communication: Moving from crisis to opportunity (3rd ed.). Thousand Oaks, CA: Sage Publications.

Waymer, D., \& Heath, R.L. (2007). Emergent agents: The forgotten publics in crisis communication and issues management research. Journal of Applied Communication Research, 1(35), 88-108.

Weiner, B. (1986). An attributional theory of motivation and emotion. New York: Springer.

Williams, D.E., \& Olaniran, B.A. (2002). Crisis communication in racial issues. Journal of Applied Communication Research, 30(4), 293-313. https://doi.org/10.1080/00909880216595

Zajonc, R.B., \& Markus, H.R. (1982). Affective and cognitive factors in preferences. Journal of Consumer Research, 9(2), 121-131. 